\title{
A 3 Year Longitudinal Prospective Review Examining the Dietary Profile and Contribution Made by Special Low Protein Foods to Energy and Macronutrient Intake in Children with Phenylketonuria
}

\author{
Anne Daly ${ }^{1, *(\mathbb{D})}$, Sharon Evans ${ }^{1}\left(\mathbb{D}\right.$, , Alex Pinto ${ }^{1}$, Catherine Ashmore ${ }^{1}$, Júlio César Rocha ${ }^{2,3}$ (D) and \\ Anita MacDonald ${ }^{1}$ \\ 1 Dietetic Department, Birmingham Children's Hospital, Steelhouse Lane, Birmingham B4 6NH, UK; \\ evanss21@me.com (S.E.); alex.pinto@nhs.net (A.P.); catherine.ashmore@nhs.net (C.A.); \\ anita.macdonald@nhs.net (A.M.) \\ 2 Nutrition and Metabolism, NOVA Medical School, Faculdade de Ciências Médicas, \\ Universidade Nova de Lisboa, 1169-056 Lisboa, Portugal; rochajc@nms.unl.pt \\ 3 Centre for Health Technology and Services Research (CINTESIS), 4200-450 Porto, Portugal \\ * Correspondence: a.daly3@nhs.net
}

Received: 19 September 2020; Accepted: 12 October 2020; Published: 15 October 2020

\begin{abstract}
The nutritional composition of special low protein foods (SLPFs) is controlled under EU legislation for 'Foods for Special Medical Purposes (FSMP)'. They are designed to meet the energy needs of patients unable to eat a normal protein containing diet. In phenylketonuria (PKU), the macronutrient contribution of SLPFs has been inadequately examined. Aim: A 3-year longitudinal prospective study investigating the contribution of SLPFs to the macronutrient intake of children with early treated PKU. Methods: 48 children (27 boys) with a mean recruitment age of 9.3 y were studied. Semi-quantitative dietary assessments and food frequency questionnaires (FFQ) were collected three to four times/year for 3 years. Results: The mean energy intake provided by SLPFs was 33\% (SD \pm 8 ), and this figure was $42 \%$ (SD \pm 13 ) for normal food and $21 \%$ (SD \pm 5 ) for protein substitutes (PS). SLPFs supplied a mean intake of $40 \%$ carbohydrate $(\mathrm{SD} \pm 10), 51 \%$ starch $(\mathrm{SD} \pm 18), 21 \%$ sugar $(\mathrm{SD} \pm 8)$, and $38 \%$ fat (SD \pm 13 ). Fibre intake met $83 \%$ of the Scientific Advisory Committee on Nutrition (SACN) reference value, with $50 \%$ coming from SLPFs with added gums and hydrocolloids. Low protein bread, pasta and milk provided the highest energy contribution, and the intake of sweet SLPFs (e.g., biscuits, cakes, and chocolate) was minimal. Children averaged three portions fruit/vegetable daily, and children aged $\geq 12$ y had irregular meal patterns. Conclusion: SLPFs provide essential energy in phenylalanine restricted diets. Optimising the nutritional quality of SLPFs deserves more attention.
\end{abstract}

Keywords: phenylketonuria; PKU; glycomacropeptide; special low protein foods; macronutrient intake; protein substitute

\section{Introduction}

In phenylketonuria (PKU), deficiency or reduced activity of the phenylalanine hydroxylase enzyme (PAH) limits the conversion of phenylalanine to tyrosine. Without intervention, intellectual disability, significant delays in developmental milestones, hyperactive behaviour with autistic features, and seizures may occur. High levels of brain phenylalanine are probably the main cause of neurotoxicity [1] by interfering with cerebral protein synthesis [2], increasing myelin turnover and inhibiting neurotransmitter synthesis [3,4]. In children with classical PKU, their only effective management option is a severely restricted low protein/phenylalanine diet that aims to lower blood 
phenylalanine levels to within a strict target range [5]. Although alternative treatments, such as sapropterin and pegvaliase (PEGylated recombinant Anabaena variabilis phenylalanine ammonia lyase $(\mathrm{PAL})$ ), have been licensed, they are only suitable for subsections of the PKU population, and access is restricted in some countries. Thereby, outcome in PKU is dependent on the early introduction of dietary treatment and the quality of lifelong blood phenylalanine control, which in turn is determined by the ability to adhere to dietary treatment.

A low protein diet aims to prevent long-term phenylalanine toxicity, with most patients tolerating $<10 \mathrm{~g} /$ day of natural protein [6]. All high biological protein foods (e.g., meat, eggs, fish, ordinary bread, pasta and flour) are not allowed [7]. The diet is supplemented with a minimal/free phenylalanine synthetic protein (protein substitute), which in classical PKU provides approximately $80 \%$ of total protein intake [8]. In the UK, the protein substitute is given with an allocated daily amount of measured phenylalanine from a range of regular foods (e.g., potatoes, peas, cereals) to meet essential requirements. Low protein foods are given without restriction and include low protein regular foods (containing protein $\leq 0.5 \mathrm{~g} / 100 \mathrm{~g}$ ), fruit and vegetables (containing phenylalanine $\leq 75 \mathrm{mg} / 100 \mathrm{~g}$ ), and special low protein foods (SLPFs) (containing phenylalanine $\leq 25 \mathrm{mg} / 100 \mathrm{~g}$ ) $[5,9]$.

In a low phenylalanine diet, SLPFs are essential safe foods, satisfying satiety, offering choice and replicating some normality in a lifelong restricted diet [7]. They are categorised as 'Foods for Special Medical Purposes' (FSMPs) and are defined as specialist foods for the dietary management of patients with a medical condition who are unable to achieve a suitable nutritional intake from regular foods. They are described as 'evidence based nutritional solutions for disorder related conditions' [10]. They are 'highly regulated' by European Union law, with 'Delegated Regulation (EU) No 2016/128' setting in place policies on composition and labelling. FSMPs should be used only under medical/health professional supervision and must be labelled according to their intended use.

SLPFs replace basic food items such as milk, bread, and pasta. They help optimise growth, provide energy to prevent catabolism, and avoid consequential raised blood phenylalanine [11]. A wide range of SLPFs may be key in helping patients sustain their dietary treatment for life, although access to SLPFs varies across Europe (European Society for Phenylketonuria (ESPKU)) [12]. Pena et al. [13] showed that the availability of SLPFs in different countries in Europe ranges from 73 SLPFs in Portugal to 256 in Italy, while no information was available for some countries. Only a few specialist companies manufacture SLPFs, and due to the constraints of a phenylalanine restricted diet, their nutritional composition consists mainly of carbohydrate and fat. Their taste and aesthetic properties are prioritised over their nutritional composition, although producing acceptable, high-quality SLPFs from isolated food starches with good organoleptic properties, texture and colour is challenging. While the variety and availability of SLPFs has improved, the choice, ease of access and quality in comparison to regular foods are all still narrow, inflexible and inadequate. There is only limited data about the nutritional contribution made by SLPFs to a phenylalanine restricted diet, or the types of SLPFs that are consumed.

In a longitudinal 3-year prospective study, the aim was to evaluate the contribution of SLPFs to the energy and macronutrient intake of a group of well-controlled children with PKU on dietary treatment only. As a secondary aim, we examined the dietary patterns of children when using SLPFs routinely in their diets.

\section{Materials and Methods}

In total, 50 children ( 28 boys, 22 girls) with PKU were recruited. Of these children, 47 were European and 3 were of Pakistani origin. Study inclusion criteria: diagnosed by newborn screening; aged 5-16 years; not treated with sapropterin dihydrochloride; and 70\% of blood phenylalanine concentrations within target range for 6 months before study enrolment. The target blood phenylalanine ranges for children aged 5-12 years were 120 to $\leq 360 \mu \mathrm{mol} / \mathrm{L}$, and for 12 years and older they were 120 to $\leq 600 \mu \mathrm{mol} / \mathrm{L}$, as recommended by the European PKU guidelines [5]. Based on untreated blood phenylalanine levels at newborn screening $(<1000 \mu \mathrm{mol} / \mathrm{L})$ and dietary phenylalanine tolerance ( $>750 \mathrm{mg} /$ day), the majority of participants had classical PKU, except two children with mild PKU. 


\subsection{Protein Substitute Intake}

At enrolment, the protein substitute sources were casein glycomacropeptide (CGMP-AA), $n=31$, and amino acid supplements (AA), $n=19$. The AAs were either ready-to-drink liquid pouches providing 10, 15 or $20 \mathrm{~g}$ protein equivalent or powders made up with water to a semi-solid consistency. The CGMP-AA was a powder mixed with $120 \mathrm{~mL}$ water. It contained $20 \mathrm{~g}$ of protein equivalent, with a residual amount of phenylalanine ( $36 \mathrm{mg} / 20 \mathrm{~g}$ protein equivalent) and it was given as a drink.

Dietary intake was assessed by 2 types of dietary assessment technique:

- Three-day recorded food diary: caregivers were instructed on how to record food intake using scales, household measures or from a pictorial handbook with measured food portion sizes. A three-day semi-quantitative dietary assessment was completed, with an annual mean of 4 (range 3-6) assessments per child for a period of 3 years. Assessments were checked via face-to-face interviews by one of two trained metabolic dietitians. Portion weights of SLPFs were provided by manufacturers' information or estimated from the 'low protein' portion size picture book. At least once annually, children were observed eating one meal at home, with portion sizes weighed and checked.

- Food frequency questionnaire (FFQ): the FFQ, specifically designed for patients with PKU, contained a series of questions on the consumption of both SLPFs and regular foods, estimating the portion sizes eaten and frequency of consumption of each food item. Foods were grouped into dairy products, cereals, fats, sugar and sweet foods, drinks, fruit and vegetables, and 'meat, fish, eggs', with 'free from' or SLPF alternatives for each category. The FFQ diaries were completed at the same time as the 3-day diet diaries, with a mean of 3 (range 3-6) FFQs completed yearly, constructing a comprehensive database on the actual consumption of special low protein and regular foods.

All the dietary assessments were analysed using Nutritics Nutritional Software (v5.093) [14]. The results were compared with age and gender specific UK dietary reference values and estimated average requirements for energy (EAR) (UK Scientific Advisory Committee on Nutrition (SACN) [15]. The database included the nutrient analysis of protein substitutes and SLPFs, using nutritional information supplied by the manufacturers.

The contribution of SLPFs to macronutrient intake was calculated by age for children $\leq 11$ years and those $\geq 12$ years. This age range was chosen to match with the age-dependent upper target blood phenylalanine concentrations given by the European PKU Guidelines [5]. At the point that children reached $\geq 12$ years of age, they were then transferred to the older age group. The following macronutrients were analysed: energy $(\mathrm{Kcal})$, protein $(\mathrm{g})$, carbohydrate $(\mathrm{g})$, starch $(\mathrm{g})$, sugar $(\mathrm{g})$, fat $(\mathrm{g})$ and fibre $(\mathrm{g})$. For each subject for each year, the mean contributions of each macronutrient from protein substitute, SLPFs and regular foods were calculated, and the mean value for all subjects is presented. The annual mean total energy intake (Kcal/day) and \% EAR has been compared with UK dietary reference values or EAR for energy [15]. From the FFQ, the regularity of meals (breakfast, midday and evening meal), frequency of snacks and drinks, and the amount of foods consumed each week were also estimated. The FFQ was used to calculate the number of portions in grams of each food from the different food groups. Using this data, the mean number of grams of food eaten each week was calculated. This data complemented the dietary assessment analysis, showing the foods that were consumed regularly, but also highlighting any foods that might have been omitted from the 3-day dietary assessments. This data was not used to estimate energy or nutrient intake and was not statistically analysed, but showed the typical weekly pattern of foods consumed, and how meals were structured.

\subsection{Anthropometric Measurements}

Weight, height and BMI were measured once every 3 months by one of two metabolic dietitians. Height was measured with a Harpenden stadiometer (Holtain Ltd., Crymych, UK) and weight on calibrated digital scales (Seca, Medical Measuring Systems and Scales, Birmingham, UK model 875); both were measured to the nearest $0.1 \mathrm{~cm}$ or $\mathrm{kg}$, respectively. 


\subsection{Blood Phenylalanine Levels}

Trained parents/caregivers collected weekly early morning fasted blood spots on filter cards, Perkin Elmer 226 (UK Standard NBS). Blood specimens were sent via first class post to the laboratory at Birmingham Children's Hospital. All the cards had a standard thickness, and the blood phenylalanine concentrations were calculated on a $3.2 \mathrm{~mm}$ punch by MS/MS tandem mass spectrometry. At enrolment, the median blood phenylalanine concentrations for the previous 12 months were collected and referred to as the enrolment blood phenylalanine concentration.

\subsection{Statistical Analysis}

Mann Whitney nonparametric unpaired $t$ tests comparing two unmatched groups of data were used to compare macronutrient differences (energy, protein, carbohydrate, starch, sugar, fat and fibre) between children $\leq 11$ years and those $\geq 12$ years. The quantitative outcome measures have been summarised and descriptive statistics reported as means and differences assessed between the groups, with a statistically significant value of $p<0.05$.

\subsection{Ethical Permission}

The South Birmingham Research Ethics (REC) committee granted a favourable ethical opinion, referenced REC13/WM/0435 and IRAS (Integrated research application system) ID 129497. Written informed consent was obtained for all subjects from at least one caregiver with parental responsibility, and written assent obtained from the subject if appropriate for their age and level of understanding.

\section{Results}

In total, 48 children ( 21 girls and 27 boys) completed the study. The mean age at enrolment was 9.3 years ( $5-16$ years). There were 35 children aged $\leq 11$ years and 13 aged $\geq 12$ years.

\subsection{Subject Withdrawal}

One boy and one girl (aged 12 years) were excluded from the study as both failed to comply with the study protocol. One failed to return blood phenylalanine samples and both had poor dietary adherence.

\subsection{Dietary Prescription}

Over the study period the total mean daily dose of protein equivalent from protein substitute was $64 \mathrm{~g} /$ day (range $40-80 \mathrm{~g}$ ) or $1.5 \mathrm{~g} / \mathrm{kg}(1-2 \mathrm{~g} / \mathrm{kg}$ ) with the mean amount of prescribed natural protein $5.5 \mathrm{~g}$ protein/day (range 3-30 g) or $275 \mathrm{mg}$ phenylalanine (range 150-1500 mg)/day. The protein substitute source was AA, $n=19$ (liquid pouches (PKU Lophlex LQ, Nutricia Ltd. Trowbridge, UK. $n=1 ;$ PKU Cooler, Vitaflo International Ltd., Liverpool, UK. $n=14$ ), or powder (PKU gel, Vitaflo International Ltd., $n=4)$ ). In total 29 children took CGMP-AA (GMP study product, Vitaflo International Ltd.); $n=13$ had their entire protein substitute requirement as CGMP-AA, and $n=16$ took a combination of CGMP-AA and AA. The numbers of children taking AA products in combination with CGMP were liquid pouches $n=15$, (PKU Lophlex, Nutricia, $n=4$; PKU Cooler, Vitaflo International Ltd., $n=11$ ), and for those taking powder (PKU gel, Vitaflo International Ltd.) $n=1$.

\subsection{Energy and Macronutrient Intake}

Mean daily energy intake and \% EAR are described in Table 1 . For both age groups the energy as a percentage of EAR was age appropriate and within 5\% of the EAR. In both groups the total percentage contribution of energy from carbohydrate, protein and fat was similar. 
Table 1. Mean (standard deviation) total energy intake, percentage of EAR, and the contribution of carbohydrate, protein and fat as a percentage of mean total energy intakes in children $\leq 11$ years and $\geq$ 12 years, and for the combined age groups over the 3-year study period.

\begin{tabular}{|c|c|c|c|}
\hline $\begin{array}{c}\text { Year } 1 \text { to } 3 \\
\text { Mean Intake (SD) }\end{array}$ & $\begin{array}{c}\leq 11 \text { years } \\
n=35\end{array}$ & $\begin{array}{c}\geq 12 \text { years } \\
n=13\end{array}$ & $\begin{array}{c}\text { All Children } \\
(\leq \mathbf{1 1} \geq \mathbf{1 2} \text { years }) \\
n=48\end{array}$ \\
\hline $\begin{array}{c}\text { Energy intake } \\
\text { Kcal/day }\end{array}$ & $\begin{array}{l}1921 \\
(255)\end{array}$ & $\begin{array}{l}2224 \\
(417)\end{array}$ & $\begin{array}{l}2059 \\
(394)\end{array}$ \\
\hline$\%$ EAR & $\begin{array}{l}105 \\
(21)\end{array}$ & $\begin{array}{c}95 \\
(13)\end{array}$ & $\begin{array}{c}99 \\
(15)\end{array}$ \\
\hline \multicolumn{4}{|c|}{ Mean $\%( \pm S D)$ energy contribution from carbohydrate, protein and fat } \\
\hline Carbohydrate & $\begin{array}{l}58 \\
(4) \\
\end{array}$ & $\begin{array}{l}56 \\
(7) \\
\end{array}$ & $\begin{array}{l}57 \\
(5)\end{array}$ \\
\hline Protein & $\begin{array}{l}15 \\
(3)\end{array}$ & $\begin{array}{l}14 \\
(4)\end{array}$ & $\begin{array}{l}14 \\
(4)\end{array}$ \\
\hline Fat & $\begin{array}{l}27 \\
(4)\end{array}$ & $\begin{array}{l}28 \\
(7)\end{array}$ & $\begin{array}{l}28 \\
(5)\end{array}$ \\
\hline
\end{tabular}

EAR, estimated average requirement. SD, standard deviation. EAR for energy was $2175 \mathrm{kcal}$ (1422-2809) [15]. Calculated by taking the median (range) for the combined ages and gender. Kcal Kilocalories.

\subsection{Contribution of SLPFs to Mean Macronutrient Intake}

\subsubsection{Energy Intake}

The total mean energy intake in the combined age groups was $2059 \mathrm{Kcal} / \mathrm{day}$, of which the percentage mean energy intake from SLPFs was 33\% (SD \pm 8 ), regular foods $42 \%(\mathrm{SD} \pm 13$ ) and protein substitute $21 \%(\mathrm{SD} \pm 5)$ (Table 1$)$. Of the total energy, $2 \%(\mathrm{SD} \pm 3)$ was provided by phenylalanine/natural protein containing foods (potatoes, crisps, and vegetables with a phenylalanine content $\geq 75 \mathrm{mg} / 100 \mathrm{~g}$ protein).

Table 2. Mean (standard deviation) contribution of calories and grams per day from carbohydrate (including starch and sugar), fat and protein to mean total energy intake for all children over the 3-year study period.

\begin{tabular}{|c|c|c|}
\hline \multirow[b]{2}{*}{ Macronutrient } & \multicolumn{2}{|c|}{$\begin{array}{c}\text { All Children } \\
(\leq 11 \geq 12 \text { years }) \\
n=48\end{array}$} \\
\hline & Mean kcals/day $( \pm$ SD) & Mean g/day $( \pm$ SD) \\
\hline Energy & $\begin{array}{l}2059 \\
(394)\end{array}$ & - \\
\hline $\mathrm{CHO}$ & $\begin{array}{c}1176 \\
(60) \\
\end{array}$ & $\begin{array}{l}294 \\
(15)\end{array}$ \\
\hline Starch & $\begin{array}{l}687 \\
(24)\end{array}$ & $\begin{array}{c}174 \\
(5)\end{array}$ \\
\hline Sugar & $\begin{array}{l}477 \\
(20)\end{array}$ & $\begin{array}{c}119 \\
(5)\end{array}$ \\
\hline Fat & $\begin{array}{l}576 \\
(36)\end{array}$ & $\begin{array}{l}63 \\
(4) \\
\end{array}$ \\
\hline Protein & $\begin{array}{c}307 \\
(5)\end{array}$ & $\begin{array}{l}74 \\
(2)\end{array}$ \\
\hline
\end{tabular}

$\mathrm{SD}$, standard deviation. $\mathrm{CHO}$, carbohydrate.

The contribution of SLPFs to the mean daily intake of carbohydrate was $40 \%$ (SD \pm 10$)$, starch $51 \%$ ( $\mathrm{SD} \pm 18$ ), sugar $21 \%(\mathrm{SD} \pm 8)$ and fat $38 \%$ (SD \pm 13 ). The daily intake of sweet SLPFs (e.g., biscuits, 
cakes, and chocolate) was low, and overall contributed minimally to the energy, fat or carbohydrate intake. Table 2 describes the mean contribution of energy and grams per day from carbohydrate (starch and sugar), fat and protein to total daily energy intake.

\subsubsection{Carbohydrate Intake}

The mean intake of carbohydrate from SLPFs, regular foods and protein substitute for all children was $294 \mathrm{~g} /$ day, of which starch provided $174 \mathrm{~g} /$ day (59\%) and sugar $119 \mathrm{~g} /$ day (40\%) (Table 2).

SLPFs were the highest contributor to total carbohydrate intake, with a mean intake from bread of $50 \mathrm{~g} /$ day $(17 \%)$, pasta of $39 \mathrm{~g} /$ day $(13 \%)$ and low protein milk replacement of $9 \mathrm{~g} /$ day $(3 \%)$. The highest contribution from regular foods to mean carbohydrate intake came from drinks (carbonated and cordials) at $20 \mathrm{~g} /$ day $(7 \%)$, potatoes at $19 \mathrm{~g} /$ day $(6 \%)$, fruit at $14 \mathrm{~g} /$ day $(5 \%)$, and crisps and confectionary, both providing $12 \mathrm{~g} /$ day (4\%). Protein substitute contributed $26 \mathrm{~g} /$ day $(9 \%)$ to the total mean carbohydrate intake. Other foods making up the total carbohydrate are shown in Table 3. The only significant difference in the intake of SLPFs between children aged $\leq 11$ and $\geq 12$ years was for the low protein milk replacement, this being higher in the younger age group $(p<0.0001)$.

Table 3. Mean contribution of SLPFs, regular foods and protein substitute in grams to total carbohydrate, starch, sugar and protein intake for children with PKU.

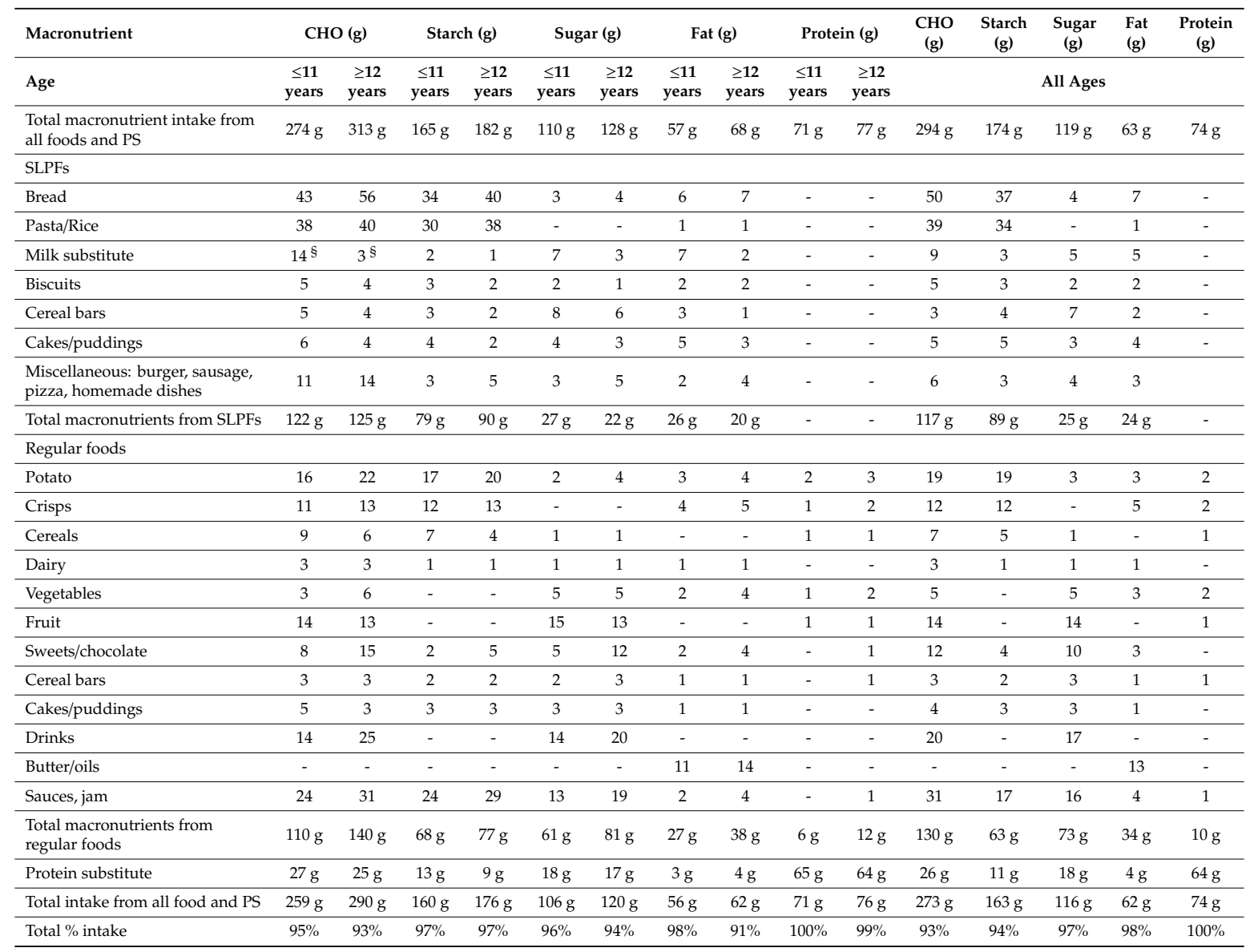

$\S p \leq 0.0001, \mathrm{CHO}$ carbohydrate, PS protein substitute, SLPFs special low protein foods. NB figures do not add to $100 \%$ due to inaccurate measurement of $\mathrm{CHO}$, starch and sugar from SLPF information.

The combined age groups had a mean daily starch intake of $174 \mathrm{~g} /$ day. The highest starch intakes were provided from low protein bread, $37 \mathrm{~g} /$ day $(21 \%)$ and pasta/rice, $34 \mathrm{~g} /$ day $(20 \%)$. Potato and crisps (phenylalanine containing foods) were the other main non-SLPF contributors to starch intake (Table 3). Protein substitutes provided $11 \mathrm{~g} /$ day $(6 \%)$ of the total starch intake. 
Sugar intake supplied by SLPFs was minimal. In the combined age groups, low protein bread provided a mean intake of $4 \mathrm{~g} /$ day (3\%). Sugar from low protein milk provided $5 \mathrm{~g} /$ day $(4 \%)$, with a higher intake in children $\leq 11$ years of age. The regular foods contributing to sugar intake were sweet drinks, providing $17 \mathrm{~g} /$ day (14\%), fruit, $14 \mathrm{~g} /$ day (12\%), and confectionary, $10 \mathrm{~g} /$ day (8\%). Protein substitutes provided $18 \mathrm{~g} /$ day or $15 \%$ of the total sugar intake. The total mean amount of free sugar, defined as sugars added to cooked or manufactured food, was $26 \mathrm{~g} /$ day $(22 \%)$, and this came largely from sweet drinks, e.g., cola, lemonade, sweets, jams, honey and condiments such as tomato sauce. The daily amount of free sugar, particularly from sweet drinks, was higher in children aged $\geq 12$ years. Free sugars represented $5 \%$ of total energy intake, in line with SACN recommendations [16]. Fruit provided a high sugar intake, but this was from natural rather than refined sugars.

\subsubsection{Fat Intake}

Fat intake provided a mean of $63 \mathrm{~g} /$ day for all children, with SLPFs supplying minimal fat intake. In the combined ages, bread supplied a mean fat intake of $7 \mathrm{~g} /$ day $(11 \%)$, and in children $\leq 11$ years milk contributed $5 \mathrm{~g} /$ day $(8 \%)$. The highest fat sources were from butter and oils, $13 \mathrm{~g} /$ day $(21 \%)$, potato crisps, $5 \mathrm{~g} /$ day $(8 \%)$, and fried potatoes, $3 \mathrm{~g} /$ day $(5 \%)$. The main sources of fat were saturated fat from oil/butter, fried potatoes and crisps. Protein substitutes provided a mean fat intake of $4 \mathrm{~g} /$ day $(6 \%)$, with some containing essential fatty acids and/or long-chain polyunsaturated fatty acids (LCPUFAs).

\subsubsection{Protein Intake}

SLPFs made no significant contribution to protein intake, while the protein equivalent from protein substitute consistently provided a mean intake of $64 \mathrm{~g} /$ day, which was $86 \%$ (SD \pm 9 ) of the total protein intake.

\subsubsection{Fibre Intake}

SLPFs provided approximately 50\% $(\mathrm{SD} \pm 23)$ of the mean daily fibre intake. Low protein bread and pasta provided higher fibre sources than potatoes, vegetables and fruits. In children aged $\leq 11 \mathrm{y}$, the total mean fibre intake was $18 \mathrm{~g} /$ day, providing $83 \%$ of the recommended intake (SACN) [16], with $9 \mathrm{~g} /$ day (50\%) from SLPFs. Children aged $\geq 12$ years consumed a mean fibre intake of $20 \mathrm{~g} /$ day, providing $82 \%$ of the recommended intake, of which $11 \mathrm{~g} /$ day (55\%) came from SLPFs. The blend of fibre was limited to the fibre sources added to SLPFs, which was commonly derived from gums and hydrocolloids.

\subsection{Median Blood Phenylalanine Concentrations throughout the 3-Year Study Period}

Statistically, the phenylalanine concentrations were significantly different both within and between the groups from enrolment to year 3 (Table 4). This group of children were well controlled, with median blood phenylalanine levels within the European PKU guidelines [5]. There was no correlation between energy intake from SLPFs and phenylalanine concentrations.

Table 4. Median (range) phenylalanine concentrations in children aged $\leq 11$ years and $\geq 12$ years at enrolment and follow up at 3 years.

\begin{tabular}{cccc}
\hline $\begin{array}{c}\text { Median Phenylalanine } \\
\mu \text { mol/L }\end{array}$ & $\begin{array}{c}\leq \mathbf{1 1} \text { years } \\
(\boldsymbol{n}=\mathbf{3 5})\end{array}$ & $\begin{array}{c}\geq \mathbf{1 2} \text { years } \\
(\boldsymbol{n}=\mathbf{1 3})\end{array}$ & $p$ Value \\
\hline $\begin{array}{c}\text { Enrolment } \\
\text { (range) }\end{array}$ & $\begin{array}{c}270 \mu \mathrm{mol} / \mathrm{L} * \S \\
(140-470)\end{array}$ & $\begin{array}{c}356 \mu \mathrm{mol} / \mathrm{L}^{*} \\
(230-600)\end{array}$ & $* p=0.003$ \\
\hline $\begin{array}{c}3 \text { year follow up } \\
\text { (range) }\end{array}$ & $\begin{array}{c}300 \mu \mathrm{mol} / \mathrm{L} * \S \S \\
(200-730)\end{array}$ & $\begin{array}{c}485 \mu \mathrm{mol} / \mathrm{L} \\
(320-895)\end{array}$ & $\begin{array}{c}* * p<0.0001 \\
\S p=0.02\end{array}$ \\
\hline & $*, * *, \$-p$-values between and within the groups.
\end{tabular}




\section{Anthropometry}

At the 3-year follow up, the median weight, height and BMI Z scores (range) were 1.0 (0.3-1.7), $0.3(-0.01-0.6)$ and $1.1(0.5-0.8)$ respectively (Table 5). Using the WHO [17] definitions of overweight and obesity, between enrolment and year 3, overweight (defined as BMI one standard deviation over the reference median) increased from $25 \%(n=12 / 48)$ to $29 \%(n=14 / 48)$, and obesity (BMI equivalent to two standard deviations over the reference median) increased from $10 \%(n=5 / 48)$ to $17 \%(n=8 / 48)$.

Table 5. Median (range) annual weight, height and BMI Z scores for all children at enrolment and follow up at year 3.

\begin{tabular}{cccc}
\hline Follow up Duration year & Weight Z Score & Height Z Score & BMI Z Score \\
\hline \multirow{2}{*}{ Enrolment } & $\begin{array}{c}0.7 \\
(-0.1-1.2)\end{array}$ & $\begin{array}{c}0 \\
(-0.2-0.5)\end{array}$ & $\begin{array}{c}0.7 \\
\end{array}$ \\
\multirow{2}{*}{ year 1 } & $\begin{array}{c}0.8 \\
(0.3-1.4)\end{array}$ & $\begin{array}{c}0.2 \\
(-0.3-0.4\end{array}$ \\
\hline \multirow{2}{*}{ year 2 } & 0.9 & 0.2 & 1.0 \\
& $(0.4-1.7)$ & $(-0.1-0.6)$ & $(0.3-1.5)$ \\
\hline \multirow{2}{*}{ year 3 } & 1.0 & 0.3 & $(0.3-1.9)$ \\
\hline
\end{tabular}

BMI: Body mass index.

\section{Food Patterns from the Food Frequency Questionnaires}

Children aged $\leq 11$ years ate regular main meals, including breakfast, midday and evening meal, with a mean of two snacks per day. Children aged $\geq 12$ years were more independent, and some would cook their own meals, usually based on pasta or bread. They had irregular meal patterns with less supervision around mealtimes. They commonly missed breakfast, eating snack foods for their midday meal particularly when in school and eating more food towards the evening after the school day had finished.

Over the 3-year study period, low protein milk replacement decreased in children aged $\leq 11$ years from a mean of $1750 \mathrm{~mL} /$ week to $1300 \mathrm{~mL} /$ week, remaining consistent at $700 \mathrm{~mL} /$ week in children aged $\geq 12$ years. In the younger age group, the mean low protein bread intake increased from $670 \mathrm{~g} / \mathrm{week}$ to $750 \mathrm{~g} /$ week at year 3 , based on an average bread slice weighing $30 \mathrm{~g}$. This was equivalent to three to four slices/day. Low protein bread intake remained consistent in children aged $\geq 12$ years of age, at $900 \mathrm{~g} /$ week (four to five slices/day). The mean intake of low protein pasta in children aged $\leq 11$ years was $600 \mathrm{~g} /$ week based on an estimated cooked portion of $200 \mathrm{~g}$ (three portions/week). This increased in children aged $\geq 12$ years from 700 to $900 \mathrm{~g} /$ week (four portions/week).

The overall daily fruit intake was low. In children aged $\leq 11$ years, the mean intake was $1200 \mathrm{~g} /$ week (two portions/day), and $700 \mathrm{~g} /$ week (one portion/day) in children $\geq 12$ years. Vegetable intake decreased over the 3 years in both groups, decreasing in children aged $\leq 11$ years from a mean of $660 \mathrm{~g} /$ week to $560 \mathrm{~g} /$ week (approximately one portion/day) and from $900 \mathrm{~g} /$ week to $700 \mathrm{~g} /$ week (one to two portions/day) in children $\geq 12$ years. Children aged $\leq 11$ years consumed a mean intake of $1200 \mathrm{~mL} /$ week of sweet drinks (mainly from fizzy drinks), with an average serving of $200 \mathrm{~mL}$ (one sweet drink/day), whilst the older group drank $2300 \mathrm{~mL} /$ week (two sweet drinks/day).

The SLPFs that were regularly eaten by the entire group of children were bread, at $92 \%(n=44 / 48)$, pasta, at $85 \%(n=41 / 48)$, and low protein milk at $77 \%(n=37 / 48)$.

\section{Discussion}

This study demonstrated that SPLFs were an essential energy source, providing over $30 \%$ of energy intake in children with PKU aged 5 to 16 years of age. The low protein staple foods bread and 
pasta made the largest consistent contribution to energy intake. There were few differences in SLPF intake between children $\leq 11$ and $\geq 12$ years of age, the exception being the younger children who consumed more low protein milk replacement. Protein substitutes provided $18 \mathrm{~g} /$ day $(15 \%)$ of the total sugar intake. Concern has been expressed about the energy content of SLPF snack foods [13], but in this study, low protein cakes, biscuits and chocolate made a minimal contribution to daily energy intake. Instead, aspartame-free sweet drinks provided the highest intake of free sugars. Some may argue that the sugar content of protein substitutes is too high; however, in children it is important to provide a source of energy to ensure nitrogen is used efficiently.

Very few studies have examined the energy contribution made by SLPFs. An Italian study, in children with PKU aged 5 to 11 years, reported that SLPFs provided $47 \%$ of energy intake [18]. In a small German study, reporting on eight children aged 6 to 16 years of age, when on dietary treatment only, the SLPFs provided 39\% of the energy intake [19], a higher energy intake than was observed in our study. Throughout Europe, SLPFs are available through a number of systems, including state national health schemes (either prescription or monthly financial family allowance), or in some countries patients/carers may be expected to make a complete or partial contribution to their purchase. It is unknown how these systems or patient acceptance impact the usage of SLPFs. In addition, it is also unknown how adherence to a phenylalanine-restricted diet and the overall quality of blood phenylalanine alters the usage of SLPFs.

In the UK, access to SPLFs is controlled. The National Society for PKU (NSPKU) provides age-defined guidance on the maximum monthly units of SLPFs that can be prescribed by community general practitioners (GPs). This is based on the assertion that SLPFs provide up to $50 \%$ of energy intake. It has been reported that both the NHS authority (e.g., the Clinical Commissioning Group or Health Board) and GPs have refused to prescribe or have limited the amounts of SLPFs that patients can access $[6,20]$. In some cases, patient requests for low protein cake mixes, or low protein cereals bars, have been rejected, even though our study indicates that these contribute a negligible energy intake. Both Cochrane et al. and Ford et al. $[6,20,21]$ have described the stigma caregivers and patients encounter when obtaining SLPFs via their GP. Due to access issues, on occasion patients are without these foods, leading to anxiety about food insecurity, which has recently been reported in PKU [22]. Even in the early 1950s, when dietary treatment commenced, it was recognised that catabolism led to increased blood phenylalanine concentrations, and therefore an adequate energy intake supplied by SLPF is a necessity [23].

It has been suggested that the uncontrolled consumption of SLPFs may cause obesity $[13,18]$, although the principle low protein foods eaten by our patient cohort were bread and pasta. However, as in other studies [10,24], our children consumed a low fat, high carbohydrate diet, leading to an imbalance in macronutrient composition. Despite energy intake only meeting recommendations, both overweight and obesity increased over the 3-year study. It has been observed from the age of one year that the energy provided by carbohydrate is higher than in healthy controls [24]. Clearly, a balanced diet prevents co-morbidities, such as metabolic syndrome, obesity, coronary heart disease and diabetes type II $[17,25,26]$. The type of carbohydrate is also an important health consideration. Insulin resistance measured by HOMA-IR (Homeostasis Model Assessment Insulin Resistance) has been shown to be higher in subjects with PKU [27], especially those who are overweight [27] or those with central obesity [28]. Similarly, the dietary glycaemic index and load was higher in children with PKU, suggesting a link between the quality of carbohydrate and peripheral insulin resistance [18]. Furthermore, lower total/LDL and higher triglyceride/HDL cholesterol ratios have been reported in children with PKU, suggesting an association between the quality of carbohydrate and triglyceride glucose index [28].

The starch sources from SLPFs, bread and pasta, eaten by children in our study were derived from starch isolated from wheat, maize and rice. Isolated starches are refined, having different physiologic properties compared to complex starch forms, and foods containing these may have a higher glycaemic index than those made from wheat flour [29,30]. However, a high intake of sugar from regular sweet 
drinks is also problematic. Many 'sugar free' drinks are unsuitable for children with PKU as they contain aspartame, a source of phenylalanine, limiting choice and increasing the glycaemic index of foods consumed. Importantly, the aspartame content of drinks may vary significantly, and the phenylalanine content is not identified on the food label [31].

Fibre sources may alter the gut microbiome, increasing the risk of chronic diseases such as inflammatory bowel disease and obesity [32]. The main fibre sources added to low protein bread and pasta were hydrocolloids. These are common additives in the food manufacturing industry, aiding texture and viscosity, but their role in gut health is limited [33,34]. Although the health benefits of hydrocolloids have been reported, there is little understanding of how these function in the intestine, or of their physiological benefits [35]. The fruit, vegetable and fibre intake of children in this study was less than the UK government's ' 5 a day' healthy eating recommendations, derived from World Health Organisation (WHO) and SACN recommendations $[16,17,36]$. Fruits and vegetables low in phenylalanine ( $\leq 75 \mathrm{mg} / 100 \mathrm{~g}$ ), except potatoes, make a valuable contribution to the dietary intake, as they can be eaten ad libitum [37]. The free consumption of these fruits and vegetables does not impact metabolic control and should be encouraged in a low phenylalanine diet as a source of beneficial fibre. Cereal and wholegrain fibres, associated with a lower risk of cardio metabolic disease and colorectal cancer, and promoted by SACN [16], are precluded in a phenylalanine restricted diet. The challenge and responsibility of manufacturers making SLPFs is to provide a source of beneficial fibre maximising gut microbiome health.

There are limitations to this study. Firstly, all dietary assessment methods are open to misinterpretation. To minimise error, the standard weights of foods were collected regularly, and at least one meal was observed and food items weighed by the same dietitian. The food frequency questionnaire was not validated, although two dietary assessment tools were used, and mealtime portion sizes were observed and weighed by a dietetic researcher to help improve the quality of the dietary data collected. The nutritional composition, including the starch and sugar content, of SLPFs was not always available on food labels, and there were some discrepancies between food labels and manufacturers' websites [29]. It was not possible to accurately assess the salt intake from food labels or from the amounts added to food in cooking or at the table.

\section{Conclusions}

In children with PKU, dietary intake is based on a lower number of regular foods, offering limited variety. This study showed that SLPFs make an important contribution to energy intake in a phenylalanine restricted diet, with consistent dietary patterns over time demonstrating long-term dependence on essential foods, such as low protein bread, pasta and milk. The intake of sugar and fat from SLPFs was minimal. SLPFs should be unlimited to all patients on a phenylalanine-restricted diet, helping their ability to sustain their dietary restriction and reducing anxiety around food insecurity. Further improvements in the nutritional quality of the diet would aid in securing longer-term health benefits and adherence to a severe lifelong regimen.

Author Contributions: Conceptualisation, A.M., A.D.; methodology, A.M., A.D.; software, A.D.; validation, A.M., A.D., S.E., A.P., C.A., J.C.R.; formal analysis, A.D., investigation, A.D.; writing-original draft preparation, A.D., A.M. Writing review and editing, A.D., S.E., A.P., J.C.R., A.M.; supervision, A.M. Funding acquisition, funding was part of PhD project from Vitaflo International. All authors have read and agreed to the published version of the manuscript.

Funding: This research was funded by Vitaflo International as part of PhD grant.

Conflicts of Interest: A.D. received research funding from Vitaflo International, financial support from Nutricia, Mevalia and Vitaflo International to attend study days and conferences. SE received research funding from Nutricia, financial support from Nutricia and Vitaflo International to attend study days and conferences. A.P. received an educational grant from Cambrooke Therapeutics and grants from Vitaflo International, Nutricia, Merck Serono, Biomarin and Mevalia to attend scientific meetings. C.A. received honoraria from Nutricia and Vitaflo International to attend study days and conferences. J.C.R. is a member of the European Nutritionist Expert Panel (Biomarin), the Advisory Board for Applied Pharma Research and Nutricia, and received honoraria as a speaker from APR, Merck Serono, Biomarin, Nutricia, Vitaflo, Cambrooke, PIAM and Lifediet. A.M. received 
research funding and honoraria from Nutricia, Vitaflo International and Merck Serono, and is a Member of European Nutrition Expert Panel (Merck Serono international), a member of Sapropterin Advisory Board (Merck Serono international), and a member of the Advisory Board Element (Danone-Nutricia). The funders had no role in the design of the study; in the collection, analyses, or interpretation of data; in the writing of the manuscript, or in the decision to publish the results.

\section{References}

1. González, M.J.; Gassió, R.; Artuch, R.; Campistol, J. Impaired Neurotransmission in Early-treated Phenylketonuria Patients. Semin. Pediatr. Neurol. 2016, 23, 332-340. [CrossRef] [PubMed]

2. Van Vliet, D.; Bruinenberg, V.M.; Mazzola, P.N.; Van Faassen, M.H.J.R.; De Blaauw, P.; Kema, I.P.; Heiner-Fokkema, M.R.; Van Anholt, R.D.; Van Der Zee, Y.A.; Van Spronsen, F. Large Neutral Amino Acid Supplementation Exerts Its Effect through Three Synergistic Mechanisms: Proof of Principle in Phenylketonuria Mice. PLoS ONE 2015, 10, e0143833. [CrossRef] [PubMed]

3. Hoeksma, M.; Reijngoud, D.-J.; Pruim, J.; De Valk, H.W.; Paans, A.M.; Van Spronsen, F.J. Phenylketonuria: High plasma phenylalanine decreases cerebral protein synthesis. Mol. Genet. Metab. 2009, 96, 177-182. [CrossRef] [PubMed]

4. Surtees, R.; Blau, N. The neurochemistry of phenylketonuria. Eur. J. Nucl. Med. Mol. Imaging 2000, 159, S109-S113. [CrossRef] [PubMed]

5. Van Wegberg, A.M.J.; Macdonald, A.; Ahring, K.; Bélanger-Quintana, A.; Blau, N.; Bosch, A.M.; Burlina, A.; Campistol, J.; Feillet, F.; Giżewska, M.; et al. The complete European guidelines on phenylketonuria: Diagnosis and treatment. Orphanet J. Rare Dis. 2017, 12, 162. [CrossRef]

6. Ford, S.; O'Driscoll, M.; Macdonald, A. Living with Phenylketonuria: Lessons from the PKU community. Mol. Genet. Metab. Rep. 2018, 17, 57-63. [CrossRef]

7. Macdonald, A.; Van Wegberg, A.M.J.; Ahring, K.; Beblo, S.; Bélanger-Quintana, A.; Burlina, A.; Campistol, J.; Coşkun, T.; Feillet, F.; Giżewska, M.; et al. PKU dietary handbook to accompany PKU guidelines. Orphanet J. Rare Dis. 2020, 15, 171. [CrossRef]

8. MacDonald, A.; Chakrapani, A.; Hendriksz, C.; Daly, A.; Davies, P.; Asplin, D.; Hall, K.; Booth, I.W. Protein substitute dosage in PKU: How much do young patients need? Arch. Dis. Child. 2006, 91, 588-593. [CrossRef]

9. Evans, S.; Adam, S.; Adams, S.; Allen, H.; Ashmore, C.; Bailey, S.; Banks, J.; Churchill, H.; Cochrane, B.; Cook, J.; et al. Uniformity of Food Protein Interpretation Amongst Dietitians for Patients with Phenylketonuria (PKU): 2020 UK National Consensus Statements. Nutrients 2020, 12, 2205. [CrossRef]

10. European Union, Supplementing regulation (EU). No 609/2013 of the European Parliament and of the Council as regards the specific compositional and information requirements for food for special medical purposes. Off. J. Eur. Union 2016, L25/30, 35-48.

11. Rocha, J.C.; Macdonald, A. Dietary intervention in the management of phenylketonuria: Current perspectives. Pediatr. Health Med. Ther. 2016, 7, 155-163. [CrossRef] [PubMed]

12. European Society of Phenylketonuria. Available online: http://www.espku.org/ (accessed on 16 September 2020).

13. Pena, M.J.; Almeida, M.F.; Van Dam, E.; Ahring, K.; Belanger-Quintana, A.; Dokoupil, K.; Gokmen-Ozel, H.; Lammardo, A.M.; Macdonald, A.; Robert, M.; et al. Special low protein foods for phenylketonuria: Availability in Europe and an examination of their nutritional profile. Orphanet J. Rare Dis. 2015, 10, 162. [CrossRef] [PubMed]

14. Nutritics, Research Edition, Version 5. 093; Nutritics: Dublin, Ireland, 2019.

15. Public Health England. Dietary Reference Values for Energy Scientific Advisory Committee on Nutrition; Public Health England: London, UK, 2011; p. 228.

16. Scientific Advisory Committee on Nutrition. Carbohydrates and Health; Public Health England: London, UK, 2015.

17. World Health Organisation. Diet, Nutrition and the Prevention of Chronic Diseases Report; WHO: Geneva, Switerland, 2002.

18. Moretti, F.; Pellegrini, N.; Salvatici, E.; Rovelli, V.; Banderali, G.; Radaelli, G.; Scazzina, F.; Giovannini, M.; Verduci, E. Dietary glycemic index, glycemic load and metabolic profile in children with phenylketonuria. Nutr. Metab. Cardiovasc. Dis. 2017, 27, 176-182. [CrossRef] [PubMed]

19. Thiele, A.G.; Rohde, C.; Mütze, U.; Arélin, M.; Ceglarek, U.; Thiery, J.; Baerwald, C.; Kiess, W.; Beblo, S. The challenge of long-term tetrahydrobiopterin (BH4) therapy in phenylketonuria: Effects on metabolic control, nutritional habits and nutrient supply. Mol. Genet. Metab. Rep. 2015, 4, 62-67. [CrossRef]

20. Ford, S.; O'Driscoll, M.; Macdonald, A. Prescribing issues experienced by people living with phenylketonuria in the UK. Mol. Genet. Metab. Rep. 2019, 21, 100527. [CrossRef] 
21. Cochrane, B.; Schwahn, B.; Galloway, P.; Robinson, P.; Gerasimidis, K. A questionnaire survey on the usage of low protein staple foods by people with phenylketonuria in Scotland. J. Hum. Nutr. Diet. 2014, 27, 533-541. [CrossRef]

22. Coakley, K.E.; Porter-Bolton, S.; Salvatore, M.L.; Blair, R.B.; Singh, R.H. Food insecurity in females with phenylketonuria. JIMD Rep. 2020, 53, 103-110. [CrossRef]

23. Bickel, H.; Gerrard, J.; Hickmans, E.M. The influence of phenylalanine intake on the chemistry and behaviour of a phenyl-ketonuric child. Acta Paediatr. 1954, 43, 64-77. [CrossRef]

24. Evans, S.; Daly, A.; Wildgoose, J.; Cochrane, B.; Chahal, S.; Ashmore, C.; Loveridge, N.; Macdonald, A. Growth, Protein and Energy Intake in Children with PKU Taking a Weaning Protein Substitute in the First Two Years of Life: A Case-Control Study. Nutrients 2019, 11, 552. [CrossRef]

25. Albertson, A.M.; Thompson, D.; Franko, D.L.; Holschuh, N.M.; Bauserman, R.; Barton, B. Prospective Associations among Cereal Intake in Childhood and Adiposity, Lipid Levels, and Physical Activity during Late Adolescence. J. Am. Diet. Assoc. 2009, 109, 1775-1780. [CrossRef]

26. Després, J. Is visceral obesity the cause of the metabolic syndrome? Ann. Med. 2006, 38, 52-63. [CrossRef] [PubMed]

27. Couce, M.L.; Guler, I.; Anca-Couce, A.; Lojo, M.; Mirás, A.; Leis, R.; Pérez-Muñuzuri, A.; Fraga, J.M.; Gude, F. New insights in growth of phenylketonuric patients. Eur. J. Pediatr. 2015, 174, 651-659. [CrossRef] [PubMed]

28. Rocha, J.C.; Van Spronsen, F.J.; Almeida, M.F.; Soares, G.; Quelhas, D.; Ramos, E.; Guimarães, J.T.; Borges, N. Dietary treatment in phenylketonuria does not lead to increased risk of obesity or metabolic syndrome. Mol. Genet. Metab. 2012, 107, 659-663. [CrossRef] [PubMed]

29. Wood, G.; Evans, S.; Pointon-Bell, K.; Rocha, J.C.; Macdonald, A. Special Low Protein Foods in the UK: An Examination of Their Macronutrient Composition in Comparison to Regular Foods. Nutrients 2020, 12, 1893. [CrossRef] [PubMed]

30. Soltanizadeh, N.; Mirmoghtadaie, L. Strategies Used in Production of Phenylalanine-Free Foods for PKU Management. Compr. Rev. Food Sci. Food Saf. 2014, 13, 287-299. [CrossRef]

31. Van Vliet, K.; Melis, E.S.; De Blaauw, P.; Van Dam, E.; Maatman, R.G.H.J.; Abeln, D.; Van Spronsen, F.J.; Heiner-Fokkema, M.R. Aspartame and Phe-Containing Degradation Products in Soft Drinks across Europe. Nutrients 2020, 12, 1887. [CrossRef] [PubMed]

32. Valdes, A.M.; Walter, J.; Segal, E.; Spector, T.D. Role of the gut microbiota in nutrition and health. BMJ 2018, 361, k2179. [CrossRef]

33. Gidley, M.J. Hydrocolloids in the digestive tract and related health implications. Curr. Opin. Colloid Interface Sci. 2013, 18, 371-378. [CrossRef]

34. Rutenberg, R.; Bernstein, S.; Paster, N.; Fallik, E.; Poverenov, E. Antimicrobial films based on cellulose-derived hydrocolloids. A synergetic effect of host-guest interactions on quality and functionality. Colloids Surfaces $B$ Biointerfaces 2016, 137, 138-145. [CrossRef]

35. Edwards, C.A.; Garcia, A.L. The Health Aspects of Hydrocolloids; Handbook of Hydrocolloids; Phillips, G.O., Williams, A., Eds.; Woodhead Publishing: Sawston, UK, 2009; pp. 50-81.

36. Public Health England. From Plate to Guide: What, Why and How for the Eatwell Model, H; PHE Publications Gateway Number: 2016451; Public Health England: London, UK, 2016.

37. Mac Donald, A.; Rylance, G.; Davies, P.; Asplin, D.; Hall, S.K.; Booth, I.W. Free use of fruits and vegetables in phenylketonuria. J. Inherit. Metab. Dis. 2003, 26, 327-338. [CrossRef]

Publisher's Note: MDPI stays neutral with regard to jurisdictional claims in published maps and institutional affiliations.

(C) 2020 by the authors. Licensee MDPI, Basel, Switzerland. This article is an open access article distributed under the terms and conditions of the Creative Commons Attribution (CC BY) license (http://creativecommons.org/licenses/by/4.0/). 